\title{
Milton Ehre, 1933-2009
}

Milton Ehre, a distinguished and beloved emeritus professor of Russian literature at the University of Chicago, died at his home in River Forest, lllinois, near Chicago, on 30 June 2009 , at the age of 76 due to the complications of Parkinson's disease. Milt was born in New York City (the Bronx), 15 April 1933, and graduated from the City College of New York in 1955. He began his lifelong teaching career in a middle school and then shifted to a high school before deciding to move on to college and graduate school teaching. He received his $\mathrm{PhD}$ from Columbia University in 1970. By then he had already been at the University of Chicago three years, and he achieved tenure there in 1972.

Milton's first book was on the subject of his dissertation, Oblomov and His Creator: The Life and Art of Ivan Goncharov (Princeton, 1973); the second was a general study of Isaak Babel's life and work for Twayne's World Authors Series (1986). Both books were written in his sophisticated literary style and with a perceptive eye for detail. Several important articles followed, including ones on Nikolai Gogol', Anton Chekhov, and Mikhail SaltykovShchedrin. Over the years he presented public papers and delivered lectures on major themes concerning, among others, Evgenii Zamiatin, Gogol', Aleksandr Pushkin, Fedor Dostoevskii, Lev Tolstoi. These lists hardly touch upon his great love of poetry, theater, and humor. Among his many successful courses, he taught a general introduction to Gogol', and in collaboration with the late Fruma Gottschalk produced The Theater of Nikolai Gogol (Chicago, 1980). (Should we be surprised that Milt's license plate read "Gogol 1"?)

In 1992 his Chekhov for the Stage appeared from Northwestern University Press. The words "for the stage" are significant, as Milt aimed to provide "stageworthy" translations that actors and actresses could speak naturally to an English-language audience while conveying the spirit of the original. Some of his translations were performed at Chicago's Court Theater; and his version of Gogol's The Government Inspector had its premiere at the Goodman Theater in Chicago. Just recently, Milt's translation of Gogol"s The Marriage was produced at the Pearl Theatre in New York. On one occasion he served as Humanist in Residence for the Chicago International Theatre Festival, and for many years he was on the committee for the annual Jefferson Awards, which happily required him to attend and judge many theater productions throughout the city.

For his scholarship and literary criticism, Milton held several distinguished research fellowships and he received grants, including from the American Council of Learned Societies, the Philosophical Society, the National Endowment for the Humanities, and twice from the Guggenheim Foundation. In 1984 a grant from the International Research and Exchanges Board allowed him to spend five months in Moscow with his family and to conduct research at the Academy of Sciences.

His greatest professional love, though, was clearly for teaching, especially undergraduates. Cultivating the minds of young college students was a passion that consumed him right down to his last years. In addition to offering courses in Russian literature, for many of those years he taught with great enthusiasm and success a section of the Humanities Core program at the University of Chicago called Human Being and Citizen (HBC), earning the respect and love of generations of first-year students. Texts began with Homer and the Bible, passed through the philosophical and the Shakespearean, and usually ended with a modern novel (only occasionally Russian). In weekly meetings of the staff Milt's voice was one of the wisest. In 1999 he received the coveted Llewellyn John and Harriett Manchester Quantrell Award for Excellence in Undergraduate Teaching. Until his illness sadly made it impossible, he continued teaching his section of $\mathrm{HBC}$ for several years after his retirement.

Only a few of Milt's sensitive translations of Russian poetry have been published. Yet who but he could render a lyric poem by Pushkin preserving its elusive tone, its simplicity, its uncannily apt choice of words? In 2004, the journal Literary Imagination published his excellent translation of Anna Akhmatova's Requiem. Many more translations of her poems, 
and some by other writers, remain in manuscript, and his family and friends hope to see them into print as a proper memorial. Milton is survived by his wife, Roberta Greene, two daughters, Joelle and Julieanne, and three grandchildren.

NORMAN W. INGHAM

University of Chicago

November 2009 